\title{
Growth-promoting effects of some biocides on grass
}

\author{
G. C. Ennik \\ Institute for Biological and Chemical Research on Field Crops and Herbage, Wage- \\ ningen, The Netherlands
}

Received 19 March, 1968

\begin{abstract}
Summary
Single application in spring or split application for each cut of O,O-diethyl O-2-pyrazinyl phosphorothioate on grass-clover swards over a 2-year period increased the grass yield with $15 \%$. The population density of free-living root nematodes was highly reduced, but this could not account for the yield increase. Application of O-2,4-dichlorophenyl O,O-diethyl phosphorothioate was much less effective on yield increase and nematode reduction.
\end{abstract}

\section{Introduction}

In pot experiments white clover could be kept growing vigorously for several months, and growth of diseased clover considerably improved, by the application of 'Nemafos' ( $25 \%$ emulsifiable concentrate (e.c.) of O,O-diethyl O-2-pyrazinyl phosphorothioate) or 'V-C 13 Nemacide' (75\% e.c. of O-2,4-dichlorophenyl O,O-diethyl phosphorothioate) (Ennik and Kort, 1966).

The same active compounds were tested in other formulations in field experiments on grass-clover swards. The results are briefly reported in this paper.

\section{Experiments and discussion}

The above-mentioned active compounds were tested in five field experiments on grassclover swards in 1966, four of these were continued in 1967. The formulations were 'Nemafos' $46 \%$ e.c. and 'AAvlitox', a wettable powder with $20 \%$ O-2,4-dichlorophenyl $\mathrm{O}, \mathrm{O}-$ diethyl phosphorothioate. The experiments were situated on sandy soils (pH-KCl varying from 4.1-5.5 and organic matter content from 3.7-4.6) with the following treatments in triplicate: (1) control; (2) single application of $16 \mathrm{ml} / \mathrm{m}^{2}$ Nemafos $(46 \%)$ in spring; (3) split application of $8 \mathrm{ml} / \mathrm{m}^{2}$ Nemafos for each cut except for the last one in 1967 (= 24-32 ml per year); (4) single application of $40 \mathrm{~g} / \mathrm{m}^{2}$ AAvlitox (20\%) in spring; (5) split application of $20 \mathrm{~g} / \mathrm{m}^{2}$ AAvlitox for each cut except for the last one in 1967 ( $=60-80 \mathrm{~g}$ per year). The plots were $8 \times 2.5 \mathrm{~m}^{2}$. Four marked areas of $0.88 \mathrm{~m}^{2}$ each were treated per plot, the chemicals being applied with a watering can in 41 water per sub-plot $\left(=4.51 / \mathrm{m}^{2}\right)$. The control sub-plots received 41 tap water. In 1966 only 3 fields with a low clover content received nitrogen at the rate of $25 \mathrm{~kg} \mathrm{~N} / \mathrm{ha}$. In 1967 all fields were fertilized with $50 \mathrm{~kg} \mathrm{~N} / \mathrm{ha}$ applied in two dressings. The total yield of the 4 sub-plots per replicate was weighed and sampled 
Table 1 Grass and clover yields per cut in $g$ dry matter $/ m^{2}$ (untreated plots) or in \% of untreated. Averages of 5 experiments in 1966 and of 4 experiments in 1967

\begin{tabular}{|c|c|c|c|c|c|c|c|c|c|c|c|}
\hline \multirow[t]{4}{*}{ Year } & \multirow[t]{4}{*}{ Cut } & \multirow{3}{*}{\multicolumn{2}{|c|}{$\begin{array}{c}g \text { d.m. } / m^{2} \\
\text { Yield in } \\
\text { of } \\
\text { untreated } \\
\text { plots }\end{array}$}} & \multicolumn{8}{|c|}{ Yield in \% of the yield of untreated plots } \\
\hline & & & & \multicolumn{4}{|c|}{ Nematos } & \multicolumn{4}{|c|}{ AAvlitox } \\
\hline & & & & \multicolumn{2}{|c|}{$\begin{array}{l}16 \mathrm{ml} / \mathrm{m}^{2} \\
\text { in spring }\end{array}$} & \multicolumn{2}{|c|}{$\begin{array}{l}8 \mathrm{ml} / / \mathrm{m}^{2} \\
\text { each cut }\end{array}$} & \multicolumn{2}{|c|}{$\begin{array}{l}40 \mathrm{~g} / \mathrm{m}^{2} \\
\text { in spring }\end{array}$} & \multicolumn{2}{|c|}{$\begin{array}{l}20 \mathrm{~g} / \mathrm{m}^{2} \\
\text { each cut }\end{array}$} \\
\hline & & grass & clover & grass & clover & grass & clover & grass & clover & grass & clover \\
\hline \multirow[t]{4}{*}{1966} & $1 \mathrm{st}$ & 267 & 81 & 102 & 91 & 105 & 99 & 103 & 100 & 105 & 100 \\
\hline & 2nd & 122 & 61 & 138 & 84 & 133 & 98 & 107 & 102 & 122 & 90 \\
\hline & 3rd & 186 & 55 & 116 & 107 & 126 & 105 & 103 & 93 & 103 & 104 \\
\hline & 4 th & 90 & 21 & 110 & 124 & 129 & 114 & 110 & 95 & 102 & 114 \\
\hline year & total & 665 & 218 & 114 & 96 & 119 & 102 & 105 & 98 & 107 & 99 \\
\hline \multirow[t]{4}{*}{1967} & $1 \mathrm{st}$ & 312 & 12 & 112 & 100 & 113 & 117 & 107 & 100 & 110 & 92 \\
\hline & 2nd & 177 & 23 & 114 & 143 & 114 & 165 & 101 & 113 & 107 & 148 \\
\hline & 3 rd & 176 & 31 & 118 & 74 & 118 & 94 & 94 & 84 & 104 & 68 \\
\hline & 4 th & 92 & 7 & 115 & 86 & 129 & 100 & 100 & 71 & 101 & 57 \\
\hline \multicolumn{2}{|c|}{ year total } & 757 & 73 & 114 & 101 & 116 & 121 & 102 & 95 & 107 & 96 \\
\hline
\end{tabular}

to determine the dry matter yields of grass and clover separately. Each year 3 or 4 cuts were obtained.

Especially in the Nemafos plots the grass occasionally suffered from yellow or brown tips due to phytotoxicity, but this did not seem to have affected growth. The average yields per cut of grass and clover are shown in Table 1. The yields of the untreated plots are given in grams of dry matter per $\mathrm{m}^{2}$, those of the treated plots are expressed as percent of the untreated ones.

In the first cut in 1966 the yields were hardly affected, but in subsequent cuts the grass yield was considerably higher on the treated plots, especially on the Nemafos plots. An increase in yield of a similar order occurred in 1967. For Nemafos, the effect averaged $15 \%$ of the control. In both years there was no significant difference between the effects of the split and single applications. In this respect the results of the experiments to be discussed below were similar. The increase in grass yield on the Nemafos plots did not result in a decrease in clover yield. With Nemafos in split application in 1967, the clover yield was even higher than on the untreated plots, indicating that also the growth of clover was improved to some extent by the Nemafos treatment.

Nematode counts, made in October 1966 in the $0-5 \mathrm{~cm}$ soil layer, showed that the number of free-living root nematodes had been reduced to a low level by Nemafos but less so by AAvlitox (Table 2), without much difference between single and split applications. The number of saprophageous nematodes was also considerably reduced by Nemafos and more so by split application.

Averaged over all experiments, Nemafos caused the greater increase in yield and the greater fall in nematodes, compared to AAvlitox. The size of both effects was independent of the frequency of application. This distinct relation between the extent of nematode death and size of yield increase may suggest that the yield response has been caused by the death of parasitic nematodes. However, the between-experiment 
Table 2 Number of free-living root nematodes (comprising the genera Pratylenchus, Paratylenchus, Tylenchorhynchus, Rotylenchus, Heterodera, Meloidogyne, Trichodorus and other Tylenchida) and saprophageous nematodes per $100 \mathrm{ml}$ of soil in October 1966. Averages of 5 experiments

\begin{tabular}{|c|c|c|c|c|c|}
\hline & \multirow[t]{2}{*}{ Untreated } & \multicolumn{2}{|c|}{ Nemafos } & \multicolumn{2}{|c|}{ AAvlitox } \\
\hline & & $\begin{array}{l}16 \mathrm{ml} / \mathrm{m}^{2} \\
\text { in spring }\end{array}$ & $\begin{array}{l}8 \mathrm{ml} / \mathrm{m}^{2} \\
\text { each cut }\end{array}$ & $\begin{array}{l}40 \mathrm{~g} / \mathrm{m}^{2} \\
\text { in spring }\end{array}$ & $\begin{array}{l}20 \mathrm{~g} / \mathrm{m}^{2} \\
\text { each cut }\end{array}$ \\
\hline Root nematodes & 2563 & 138 & 84 & 1278 & 1408 \\
\hline Saprophageous nematodes & 2003 & 1228 & 261 & 1672 & 2332 \\
\hline
\end{tabular}

variability in population density of the different nematode genera, either separately or in combination, did not parallel the variability in yield increments. Moreover, the nematode numbers were rather low in some experiments and probably below the critical level for damage. It is likely, therefore, that the yield increasing effect is at least partly attributable to factors other than the death of nematodes. Similar unexplained growth responses have been observed by other workers with other chemicals on other crops (Martin, 1966).

In two other field experiments, different application rates of Nemafos $46 \%(21 / 2,5$, $71 / 2$ and $10 \mathrm{ml} / \mathrm{m}^{2}$ for each cut or $15 \mathrm{ml} / \mathrm{m}^{2}$ in spring) and AAvlitox $20 \%(71 / 2$, $15,221 / 2$ and $30 \mathrm{~g} / \mathrm{m}^{2}$ for each cut or $40 \mathrm{~g} / \mathrm{m}^{2}$ in spring) were compared in 1966 and 1967. Application of both compounds, and more in particular of Nemafos, resulted in an increase in grass in one experiment, whereas in the other the increase was mainly in clover. In both experiments the increment appeared to be independent of time and rates of application, the lowest rate being as effective as the highest. The reduction in nematodes examined in April 1967, prior to the first treatment in that year, ran quite parallel to the yield increment: Nemafos was more effective than AAvlitox and the reduction was the same for all application rates and methods. However, the nematode numbers in the untreated plots were very low in both experiments and not likely to cause plant damage. Nor could they account for the difference in reaction of grass and clover on both fields.

Field experiments have shown that an increase in available nitrogen is a common effect of biocide application. Pot experiments indicated that under certain conditions treatment with chemicals may promote root growth (Ennik, 1966) or reduce water consumption. Additional research is needed to clarify whether and to what extent these phenomena are involved in the growth response.

\section{Acknowledgements}

Thanks are due to the Plant Protection Service, Wageningen for calculating nematode numbers, to Ligtermoet Chemie N.V., Rotterdam, Cyanamid of Great Britain Limited, London and Wiersum Chemie N.V., Groningen for providing the chemicals, and to Mr. T. Baan Hofman for technical assistance. 


\section{GROWTH-PROMOTING EFFECTS OF SOME BIOCIDES ON GRASS}

\section{References}

Ennik, G. C., 1966. Influence of clipping and soil fumigation on shoot and root production of perennial ryegrass and white clover. Jaarb. I.B.S., Wageningen, pp. 11-18.

Ennik, G. C. and Kort, J., 1966. Improvement of white clover growth with non-phytotoxic compounds known to control soil parasites. Neth. J. Pl. Path., 72: 184-195.

Martin, J. P., 1966. Influence of pesticides on soil microbes and soil properties. In: Pesticides and their effects on soils and water. ASA special Publication No. 8 Soil Sc. Soc. America, Madison, pp. 95-108. 